2017

\title{
A comparison of Catechesis of the Good Shepherd and Godly Play
}

Gerard O'Shea

The University of Notre Dame Australia, gerard.oshea@nd.edu.au

\section{Follow this and additional works at: https://researchonline.nd.edu.au/edu_article Part of the Education Commons}

This article was originally published as:

O'Shea, G. (2017). A comparison of Catechesis of the Good Shepherd and Godly Play. British Journal of Religious Education, Online First.

Original article available here:

https://dx.doi.org/10.1080/01416200.2017.1292209

This article is posted on ResearchOnline@ND at https://researchonline.nd.edu.au/edu_article/202. For more information, please contact researchonline@nd.edu.au. 
This is not the final version of this article, it is an Accepted Manuscript of the article published online in the British Journal of Religious Education 28 February, 2017, The final published version is available online:

https://dx.doi.org/10.1080/01416200.2017.1292209

O'Shea, G. (2017). A comparison of Catechesis of the Good Shepherd and Godly Play. British Journal of Religious Education, Online First. doi: 10.1080/01416200.2017.1292209 


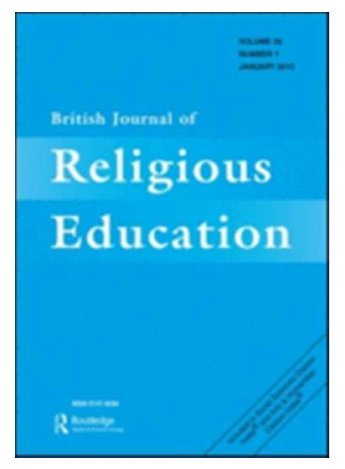

\section{A Comparison of Godly Play and Catechesis of the Good} Shepherd

\begin{tabular}{|r|l|}
\hline Journal: & British Journal of Religious Education \\
\hline Manuscript ID & CBRE-2015-0046.R1 \\
\hline Manuscript Type: & Original Article \\
\hline Keywords: & Pedagogy, Teaching Approaches, Theology \\
\hline \multicolumn{3}{c}{$\begin{array}{r}\text { SCHOLARONE } \\
\text { Manuscripts }\end{array}$} \\
&
\end{tabular}




\section{A Comparison of Catechesis of the Good Shepherd and Godly Play}

\section{Introduction}

In recent years, two Montessori based methods of religious education have come to prominence across many Christian Churches. They are called Catechesis of the Good Shepherd, developed by Sofia Cavalletti, and Godly Play adapted by Jerome Berryman. Educators have been struck by the capacity of both programs to integrate much of what is best in contemporary learning theory with the essentials of the Christian message. Cavalletti and Berryman were on friendly terms and collaborated to some extent on their projects. In a tribute to Cavalletti's after her death in 2011, Berryman told the following anecdote which offers some insight into their differing perspectives. He said that at one point, he told Cavalletti that he intended to prepare materials for every one of the parables. Her single word response disarmed him: "Why?" she asked. In many ways, that question sums up the differences in their perspectives. This paper will bring out these contrasts by looking at the distinctive work of Cavalletti and Berryman in turn, beginning with a brief account of their common roots in the theories of Maria Montessori. It will then illustrate the differences between the two approaches in three major areas: first in their understandings of the Imago Dei; second in the meaning of and the link between sacraments and the Scriptures; and finally, in the organisation of classes. From this demonstration, it will be concluded that the two programmes have a natural constituency: Catechesis of the Good Shepherd among Catholic, Orthodox and other "sacramental" Churches, and Godly Play among Evangelical and Protestant Churches.

\section{The Work of Maria Montessori}

Montessori's work is not unfamiliar in Catholic circles; her approach has long been recognised as uniquely suited to the integral formation of the human person which looks to Christ himself as the fullness and best expression of what humanity is meant to be (See John Paul II, 2001, 32). This was recognised by Pope Paul VI (1970) in an official statement:

'She [Maria Montessori] was convinced that the pedagogy inherent in the liturgy contained the same principles as her own theory of secular education, and she resolutely took the ways towards liturgical renewal which were opened by Saint Pius $\mathrm{X}$. Just as the school had to be the children's home, so the church had to be the home of God's children.'

Pope John Paul II (1995) drew attention to the uniquely feminine insights that allowed Montessori to perceive a reality about human nature and human learning that had escaped others. He regretted the fact that many of her ideas may have been rejected on this basis. 'Unfortunately, looking at the historical reality objectively, it must be noted with regret that, also on this level, women have suffered constant marginalization.' The application of Montessori principles in other Christian Churches has been of more recent origin, but recognition from authoritative sources within these denominations is by no means lacking.

Moreover, in 2005, Angeline Lillard, then working at Stanford University and now a professor of educational psychology at the University of Virginia, undertook an the enormous project of examining Montessori's principles in the light of scientific research to determine which of these stood up to rigorous examination, and which ones did not. After the study, Lillard wrote the following lines in the introduction to her book:

'The delegates at Oxford University Press asked that I write a balanced assessment of Montessori, pointing out where the evidence is not supportive as well as where it was. 
I have done my best to do this, but there is a real problem. Their assumption, like my original one, was that Montessori must have aspects that are supported by research and aspects that are not. Yet her major ideas... are supported by a strong body of evidence in developmental psychology. Some of her main developmental ideas that did not take hold until later and are rarely attributed to her are now mainstream. None of Montessori's ideas that I would consider central have been disproven. Others are not researched.' (Lillard, 2005, ix-x)

\section{The Work of Sofia Cavalletti - Catechesis of the Good Shepherd}

In the application of Montessori principles to the field of religious education, Sofia Cavalletti has been a pivotal figure. She began her collaboration in the field of religious education with Gianna Gobbi, a professor of Montessori education, in 1952. Together, they developed what came to be known as the Catechesis of the Good Shepherd, painstakingly creating materials that would serve the religious needs of children from the ages of three to twelve years. Taking the Montessori sensitive periods as their starting point and guided by the response of real children as their "reality check," Cavalletti and Gobbi refined their understanding of the religious experiences that children needed at each stage of their development. In Gobbi's words: 'The content of the Christian message needs to vary according to the developmental stage of the child... the changing deep needs of the respective developmental period call for a different 'face of God' to be presented' (Gobbi, 1998, 89). Cavalletti and Gobbi noticed that by the age of three years, children were not only capable of entering into a relationship with God, but they seemed eager to do so. The starting point for such children had already been indicated by Montessori herself. She had pointed to the opening lines of a poem, Ode on the Intimations of Immortality, by William Wordsworth as indicative of a timeless truth for humanity:

'There was a time when meadow, grove and stream

The earth and every common sight

To me did seem appareled in celestial light

The glory and the freshness of a reverie.'

Thomas Aquinas, in more prosaic language, had provided a succinct analysis of the same truth: 'There resides in every man a natural desire to know the cause of any effect he sees; and thence arises wonder in men.' (Summa Theologica, I, 12, 1)

Cavalletti discerned the central role of "wonder" in a child's religious development and she realized that for young children (and indeed for every human being), wonder is evoked by "an attentive gaze at reality" (Cavalletti, 1992, 139).. Consequently, the children were encouraged to begin their relationship with God by recognizing, one by one, gifts offered to them in the created world. To meet this need, the Montessori "practical life" works were found to be ideal. Children were to engage in tasks such as flower arranging, slow dusting, leaf washing and the like. The experience of Montessori classrooms for over a hundred years has born witness to the effectiveness of this approach. Engagement with concrete "hands on" activities seem to be the basis not only of religious development, but learning of any kind.

It was from these two starting points that the whole project took off. The careful observation of the needs of real children had identified the basic stages of learning, summed up in a simple axiom: first the body, then the heart, then the mind. As the twentieth century progressed, these two women (both highly educated in their fields) evaluated new ideas in education, Biblical scholarship and theology. Cavalletti and Gobbi did not easily fall prey to a widely reported educational phenomenon, the "band wagon effect." They were "action 
researchers" who tested their theories on real children. If their materials failed to engage their subjects, they were discarded and alternatives sought. Both Cavalletti and Gobbi wrote books and delivered courses to share the fruits of their research, each one of them bringing out a different aspect of the project. There are two core texts which provide closely argued and illustrated descriptions of their findings. The Religious Potential of the Child outlines Cavalletti's views about the child from three to six years of age, while the sequel, The Religious Potential of the Child, Six to Twelve Years describes the next level. Gobbi's book Listening to God with Children outlines the way in which classic Montessori theories particularly her ideas on the planes of development and sensitive periods - have been applied to the context of children's religious development. Two further works of Cavalletti should be regarded as foundational to understanding the Catechesis of the Good Shepherd. Living Liturgy is widely regarded as one of the most "accessible" books ever written on the subject. Finally, the complementary areas of Salvation History and the Scriptures are presented in History's Golden Thread.

The effect of Cavalletti and Gobbi's work has been impressive. The Catechesis of the Good Shepherd has now won over passionate supporters throughout the world who have devoted much of their own time and resources to its ongoing implementation and promotion. A world-wide "action research" community has taken shape and the work continues to expand through National Associations of the Catechesis of the Good Shepherd. This programme has now come to embrace all of the major themes required for an integrated education in the Catholic Faith: Scripture, Liturgy and Sacraments, Prayer, Moral Formation, Practical life activities, profound doctrinal understandings and Salvation History. All of these are brought together primarily under a unifying force described by Cavalletti as Mystagogy the liturgical catechesis which draws human beings to participate in the mystery of Christ as revealed in the Scriptures and Tradition. Vindication for this approach has come most recently in the apostolic exhortation of Pope Francis, Evangelii Gaudium, which draws attention to this aspect of religious education in very similar terms to those of Cavalletti: "a progressive experience of formation involving the entire community and a renewed appreciation of the liturgical signs of Christian initiation." (Evangelii Gaudium, 2013, 166) Moreover, the pope also makes it clear that he expects religious education generally to move in this direction: 'Many manuals and programmes have not yet taken sufficiently into account the need for a mystagogical renewal...' (Evangelii Gaudium, 166) One of the most striking and commonly reported phenomena of the Catechesis of the Good Shepherd is that even very young children seem to be able to arrive at profound theological understandings for themselves - without being told. Again, it is Pope Francis who has offered support from the contemporary Catholic Church for this view: 'The presence of the spirit gives Christians a certain connaturality with divine realities, and a wisdom which enables them to grasp those realities intuitively, even when they lack the wherewithal to give them precise expression.' (Lumen Fidei, 2013, 119)

Time and again, in every culture in which it is tried, catechists have reported that children respond profoundly to the mystical meanings that deduce for themselves from the concrete materials they have used. This in turn appears to have enhanced their reading of the Scriptures, their participation in the Liturgy, and their prayer life. There is a poignant account related in The Religious Potential of the Child about a simple sets of materials - cruets for pouring water and wine into a chalice. Allegorically, the wine represents Jesus and the water represents us. Cavalletti tells the story this way...

'We will never forget seven-year-old Massimo, who continued to repeat this exercise for so long a period of time. The catechist, thinking that he was doing it out of laziness, came up to him several times to introduce him to some other 
work; but Massimo's facial expression was intent and rapt and he was trying to explain the meaning of what he was doing as he repeated the various actions... Finally - it was almost at the end of the year - he managed to say: 'A few drops of water and a lot of wine, because we must lose ourselves in Jesus'... In the end Massiomo had known how to express it with words worthy of a mystic.'

(Cavalletti, 1992, 92)

Similar accounts of children's profound yet simple theological discoveries are chronicled in the Journals of the Catechesis of the Good Shepherd, made available through the United States National Association of the Catechesis of the Good Shepherd. A comprehensive set of materials which has proven very effective in the Catholic formation of young people has now been worked out and is in constant use. Yet there remains a pastoral problem to be addressed. While it may be clear that religious formation is at its optimum when it follows the natural developmental sensitive periods, in many if not most cases, this is not possible. By the time the process of catechesis begins, the sensitive period may have already passed. This is necessarily the case for adult converts. What is to be done in this situation? Perhaps an analogy already referred to will provide the best answer. Is it possible to learn a language after the sensitive period is over? Of course, but it is just more difficult.

It seems that the sequence by which we learn in a given circumstance has striking formal similarities with the sequence which unfolds across the developmental span. Essentially, there remain four basic stages. First, it is necessary to "gather data" - just as the youngest child with an absorbent mind engages in the process of data gathering. Once the data is gathered, the learner must look for connections and try to discern a pattern - a "big picture" to explain the data. This is the typical task of the 6-9 year old child. The third stage sees the learner testing the big picture that has been created by applying all existing data, and seeking out new data to see whether or not it too fits into the pattern. If it does not, the "big picture" must be modified or replaced. The 9-12 year old children are generally involved in this process as their major focus of interest. Finally, the learner must personalize the information and theories developed. How is this relevant to "me" - does it have an application that "I" find relevant? This is the approach of the typical need of the adolescent.

The four stages of learning, namely, data gathering, creating a "big picture", testing the "big picture" and finally personalizing, can be pursued at any age. The sequence is usually the same. In terms of religious development, the starting point that a very young child with an absorbent mind needs is the same as the one needed for an adult with no experience. Just as the young child must gather and name the data of the faith; just as this same child must come to know of the care, love and protection of God - so too must neophytes of any age begin. A child of ten who has no religious experience still needs to move back to the foundational experience of God's love before proceeding. The same is true of the adolescent or the adult. Even if the sensitive periods are missed, the same basic experiences must follow one another in more or less the same order. What are these learning experiences? This area is not fully developed and any answer must still be experimental and tentative.

\section{The Work of Jerome Berryman - Godly Play}

Godly Play was developed by Jerome Berryman who freely acknowledges his debt to Sofia Cavalletti, under whom he studied. As a minister of the Presbyterian, and subsequently, the Protestant Episcopal Church, Berryman undertook to adapt the work of Cavalletti for use in a mainline Protestant context. Berryman's educational methodology has been updated in 
the 2009 edition of a work he first published in 1995, Teaching Godly Play: How to Mentor the Spiritual Development of Children (Berryman, 2009. It is evident in this text that his educational methodology has moved forcefully in the direction of an emphasis on the role of language as the foundational principle of his system. As part of his later text, Berryman asks the rhetorical question: 'How do you know Godly Play when you see it?' In answer, he articulates a series of principles as follows (see Berryman, 2009, 118-119):

'Is God's presence in the process?

Is the play voluntary and within the safety of the constructive limits of choice provided by the method?

Is the concentration deep, especially during the presentations and responses?

Is the involvement in the core lessons and their extensions (enrichment lessons and other supporting materials) for itself and not because of punishment or rewards? Is pleasure experienced by the children and adults involved?'

Godly Play is described as proceeding in a 'living spiral by which the whole process is organised to interplay with the developmental stages of early, middle and late childhood' (Berryman, 2009, 119). This spiral, Berryman writes, is driven by a kind of circular energy which moves it outwards in three ways: 'the circle of the creative process in each child, the circle of the dynamics in each class and the turning of the circle of the Church year.' (Berryman, 2009, 119). Berryman puts a great deal of emphasis on religious education as the acquisition of a Christian language system and uses the image of the spiral to explain this in the way the Godly Play works out in practice.

'The children enter the domain of Christian language (the room). They then move through the activities of the lesson and the related wondering. The children then move one at a time to get out their work during the response time. The feast and then the goodbye follow. This movement follows the deep structure of Christian worship and is an indirect preparation for the children to be involved directly in the worship of the congregation.' (Berryman, 2009, 119).

\section{Differences Between Godly Play and Catechesis of the Good Shepherd}

As much of the methodology and content of Godly Play is based on with Catechesis of the Good Shepherd, it will not be repeated here. The focus from this point will be on the contrast between the views of Cavalletti and her followers and the adaptations that have taken place within Godly Play at the instigation of Berryman. There are four major areas which stand out in this: the Imago Dei, sacraments and sacramentality, pedagogy and the organisation of the classes.

\section{Imago Dei - The Image of God}

One of the unique features of Christianity is the claim found in the Bible that human beings have been created in the image of God - the Imago Dei (see Genesis 1:26-27). In all of her work, it is clear that Cavalletti followed the usual Catholic interpretation of the Imago Dei, namely, that human beings bear the image of God in their spiritual/ rational faculties of intellect and will. Through these capacities, human beings share something in common with God - there is an ontological similarity (see Catechism of the Catholic Church, 1993, 356358). According to this view, human persons are embodied spirits in whom the spiritual faculties of mind and will work with the physical body. This indispensable role for the senses in human learning was first articulated by Aristotle and taken up by St Thomas Aquinas and is known as the peripatetic axiom - 'nothing in the mind that is not first in the senses'. It is 
also clear that another important dimension of human existence has found its way into Cavalletti's work from the contemporary Catholic insights of John Paul II's Theology of the Body. Genuinely human existence must embrace the dimension of relationship, and so any proper unfolding of human life and learning must take place in a community (or to put it more accurately - a communio).

Building on this understanding of the human person, it is held that the natural capacity of the human intellect for acquiring knowledge can be raised to a higher level by receiving the supernatural gift of faith - a knowledge of divine realities which is beyond normal human abilities. The natural capacity of the human will makes us capable of freely choosing, and therefore of loving. This too can be raised to a higher perfection through the supernatural gift of caritas - the perfect love that allows one to love with the love of God. The Catechism of the Catholic Church refers to these three capacities as the theological virtues, and teaches that they are "infused" at Baptism. The human person is drawn into the life of the Trinity by taking existing human faculties - the intellect, the will and the senses - and raising them to a new level of meaning and existence, integrating them with the grace of the Holy Spirit. This is the "grand design" which underpins Catechesis of the Good Shepherd. A wide variety of ordinary human activities serve as the starting point for grace to elevate nature to its true destiny.

Berryman's interpretation of the doctrine of the Imago Dei follows a different trajectory. He does not stress or even refer to the notion of an ontological similarity of rational faculties. Rather, he places the emphasis on the dimensions of creativity and language.

'The theological concept of the Imago Dei argues that we are creatures made in the image of the Creator and are, therefore, creators as well. God also gave us the gift of language to name God's creatures (Genesis 2:19) and to use in our creating. In the letter to the Hebrews the author begins by talking about the many ways "God spoke to our ancestors" and that now "in these last days he has spoken to us by a Son"

(Hebrews 1:1-2). This Son is called the "the Word" in John's gospel (John 1:1-5). These few references illustrate how both the Hebrew Scriptures and the Christian Scriptures have closely aligned God, creation and speech.' (Berryman, 2009, 232-3)

Berryman's approach in Godly Play recalls the classic Protestant perspective by placing a strong emphasis on the Word and giving a lesser (though, in Berryman's case, still a relevant role) to the Liturgy. In his view, human beings are given access to spiritual reality primarily through language and symbol, with some further support offered through the Liturgy, with two sacraments and five "sacramental rites".

'When Christian language is learned by the Godly Play approach, it is learned as a means to know God and to make existential meaning... It is remembered because the Christian language system is useful to know God and to make existential meaning, which are both deeply satisfying experiences.' (Berryman, 2009, 120)

In practical terms, this results in more prominence being given to the "story" and the "story teller". It also results in the Godly Play materials being a largely symbolic representation of events - accessible through felt figures - rather than the more realistic three dimensional figures recommended by Cavalletti.

Sacraments and Sacramentality 
Closely related to his interpretation of the Imago Dei, Berryman also presents an alternative view of what a sacrament is. In a recent book, Children and the Theologians, he has proposed that children should be seen as sacraments. His understanding of this doctrine is clearly different from the Catholic position:

'It is startling to think of children as sacraments.... What is even more startling, however, is to realize that at some level we already know this to be true, despite not being accustomed to thinking about children in this way.' (Berryman, 2009, 120.)

'Part of the strangeness of thinking about children as sacraments is that we are accustomed to thinking about sacraments as being something we can control better than children, like a touch, oil, water, bread, or wine. The profound meaning of Jesus' breaking bread and sharing wine in the first century must have seemed as strange and out of control to those people as thinking of children as sacraments is to us, especially when compared to what the priests did exclusively in the temple. But isn't that the point? A means of grace is not meant to be able to be controlled by people because the grace is God's.' (Berryman, 2009, 131)

In contrast, the Catechism of the Catholic Church states:

'The sacraments are efficacious signs of grace, instituted by Christ and entrusted to the Church, by which divine life is dispensed to us. The visible rites by which the sacraments are celebrated signify and make present the graces proper to each sacrament. They bear fruit in those who receive them with the required dispositions.' (Catechism of the Catholic Church, 1993, 1131.)

The Catholic understanding is not exhausted by this description, of course, but it does rule out the possibility of taking the same stance as Berryman in proposing "children" as sacraments in the formal sense. In Cavalleti's view, the normal human access to "the spiritual" is through the senses and this is usually referred under the heading of sacramentality. Anything in the created universe, not just children, can provide an opportunity to encounter the divine - a flower, a sunset, a particular human being; every one of these can be an opportunity to turn the human mind and heart to God. Saints such as Francis of Assisi and Therese of Lisieux have made it clear that for human beings, it is through using ordinary things that we can make progress towards holiness. Cavalletti believes the same thing. Sacraments, on the other hand, have a more restricted meaning. They refer to particular rites, initiated by Christ, to give unambiguous access to the grace of God. In his encyclical, Lumen Fidei, Pope Francis has underscored the essential educational role that sacraments have for Catholics:

'There is a special means for passing down this fullness [of the true light born of an encounter with the true God], a means capable of engaging the entire person, body and spirit, interior life and relationships with others. It is the sacraments, celebrated in the Church's liturgy.' (Pope Francis b, 2013, 40)

Cavalletti placed great emphasis on the connection between the Sacramental Liturgies and the Scriptures, in the same terms noted in the apostolic exhortation, Verbum Domini. Here the Liturgy is referred to as the 'privileged setting for the word of God' (Benedict XVI, 2010, 52-56). In Cavalletti's view, neither the Scriptures nor the Liturgy can be properly understood without the other. Berryman's Godly Play does not reject this connection, it simply does not feature prominently, and the emphasis is primarily on the story and the storyteller. 


\section{Pedagogy}

Brendan Hyde has argued that Berryman's work represents a kind of "platform shift" - an updating of Montessori's insights to a new level, which has now superseded Cavalletti's earlier work (See Hyde, 2011, 341-353). Given the research of Angeline Lillard, cited above, together with the contemporary insights found in the Training Manuals of the national Association of the Cathechesis of the Good Shepherd, this argument does not seem to be sustainable. In terms of contemporary pedagogical research, it can even be argued that the pedagogy practised in Catechesis of the Good Shepherd is supported by an enormous weight of research, and in this area demonstrably outpaces Godly Play. It is undeniable that Berryman has taken some Montessori concepts in a new direction theologically, but this cannot be said to have taken Montessori education to a new level. Furthermore, the work of Professor John Hattie - currently the world's most frequently cited educationalist - vindicates the classic approach of Montessori's pedagogy as it is used in Catechesis of the Good Shepherd. In his book, Visible Learning, Hattie identifies a most of the best known teaching practices and ranks them according to their effectiveness. The approach used by Catechesis of the Good Shepherd incorporates all of the best teaching practices recommended by Hattie to a much greater extent than those used by Godly Play (see Hattie, 2009, 297- 300). Even so, neither Godly Play nor Catechesis of the Good Shepherd can be accused of stagnating. The differences between the two, it would seem, are more strongly grounded in different theologies rather than in educational theories.

\section{Conduct of Sessions: Godly Play}

Godly Play depends heavily on the adult guide, the "storyteller", who mediates the meaning of the Scriptures through methods of skilled storytelling. This storytelling follows a set script and the curriculum unfolds according to a three year spiral. Participants are expected to follow a designated procedure.

'The way that a Godly Play class works can also be thought of as a circle. The children enter the domain of Christian language (the room). They then move through the activities of the lesson and the related wondering. The children then move one at a time to get out their work during the response time. The feast and then the goodbye follow. This movement follows the deep structure of Christian worship and is an indirect preparation for the children to be involved directly in the worship of the congregation.' (Berryman, 2009, 120)

The method unfolds in three stages:

First, there is a preliminary stage in which the Godly Play environment is set up before beginning any lessons. The environment consists mainly of an open space for sitting in a circle, and the variety of felt materials that will be needed for presentations. Some art materials are also set up.

Second, the children gather in a circle with the story Teller (teacher) taking a designated place in the circle. The presentation for the day is almost always taken from the Bible, and this is delivered using materials cut from felt - sometimes they are made from other materials. The stories follow a designated script, which the teacher is required to follow and the process is the same for every developmental level. The presentation of the story 
is the main focus of the lesson, and the teacher spends a great deal of time drawing out the implications with the children.

The third stage involves the children in a process of further reflection. At this point, the children may use other materials that have captured their imagination, and there is some scope for artistic responses.

One further significant departure which Berryman makes from Montessori theory is in the area of repetition. Berryman claims that it usually takes three encounters with a lesson for the child to properly comprehend it. This takes place, typically, once a year for three years repeated in concert with the liturgical season (see Berryman, 2009, 119). It would seem that this narrowing down of the opportunities for repetition to only three is not adequate in forming a neural pathway. Clearly, this is a point of serious divergence with the educational approach used in Catechesis of the Good Shepherd, where students return to the same set of materials many more times than this. Recent research indicates that, even in the relatively simple field of vocabulary recognition, more than ten repetitions seem to be necessary before any genuine mastery can be achieved (see Webb, 2007, 46-65).

\section{Conduct of Sessions: Catechesis of the Good Shepherd}

Catechesis of the Good Shepherd attempts to allow participants to "discover" meaning for themselves. Students are exposed to a carefully prepared environment in which they engage with materials through repeated encounters. Both Montessori and Cavalletti preferred the term work rather than play since it implies a dignity that should be afforded to what the child is doing; this is an acknowledgement that they are constructing their personalities and their relationship with God through their own actions and responses. The role of the adult (catechist) is to give a very basic and brief presentation of the materials and then allow the children to use the particular set of materials to which they are drawn. They are left to spend whatever amount of time they need to gain a satisfying meaning, and are encouraged to reflect on the same set of materials repeatedly - either by actually using them, or by engaging in other reflective or artistic activities related to them. The catechist keeps a note of the child's activities and may then remind children of things they may wish to look at again.

The Catechesis of the Good Shepherd also follows three basic stages, but the details of how these operate depend on the developmental stage of the children. Typically, they are divided into 3-6 year olds, 6-9 year olds and 9-12 year olds, but there is scope for overlap as to where children are to be placed, based on their individual development.

First, a great deal of effort goes in to setting up the environment, and placing all of the necessary works where the children will be able, in due course, to perceive the connection among each of the elements. There is also a go stocked with a variety of art, drawing and writing supplies which the teacher will use to train the children to make independent responses to the materials the children are working with. In the preliminary stage, much time is expended on showing the children how to use the space in a considerate and ordered way - according to standards of grace and courtesy.

The second stage is very brief and simple. The catechist may present a small number of new works which are added to the repertoire that the children are free to work from. Typically, the presentations will follow the Liturgical season, and will alternate 
between Biblical and Liturgical materials to reinforce the link between the two. Once this is over the children are free to choose what they would like to do next from the range of designated responses or from the materials already presented.

The third stage consists of calling the children together for prayer and ensuring that the environment is restored in the belief that the space is made special through acts of routine care, and by working together for this purpose, the children help to build a community.

\section{Conclusion}

While both Catechesis of the Good Shepherd and Godly Play have proved their worth as instruments of Religious Education, each one works better in its own distinctive context. Godly Play with its heavy emphasis on the Scriptures as "story" and the interpretation of the Imago Dei in terms of a "symbolic/ language" mediation of divine reality fits in well with the insights of mainline Protestant Churches. Catechesis of the Good Shepherd interprets the Imago Dei in terms of sacramentality and ontological similarity - grace building on nature through the use of the material/spiritual composition of the human person. This is ideally suited for use in Catholic, Orthodox and Anglo-Catholic contexts.

\section{References}

Benedict XVI Verbum Domini (2010)

Berryman, Jerome W. 2009a. Children and the Theologians: Clearing the Way for Grace. (New York: Morehouse Publishing)

Berryman, Jerome W. 2009b. Teaching Godly Play: How to Mentor the Spiritual Development of Children. (Denver: Moorhouse Education Resources)

Berryman, Jerome W. 1995. Teaching Godly Play: The Sunday Morning Handbook. (Nashville, TN: Abingdon Press)

Berryman, Jerome. 2002. The Complete Guide to Godly Play: An Imaginative Method for Presenting Scripture Stories to Children. (Denver, CO: Living the Good News)

Berryman, Jerome W. 2013. The Spiritual Guidance of Children: Montessori, Godly Play, and the Future (New York: Morehouse Publishing)

Catechism of the Catholic Church. 1994. (Homebush: St Pauls/ Liberia Editrice Vaticana)

Cavalletti, Sofia. 2012. History of the Kingdom of God: From Creation to Parousia. Part 1. (Chicago: LTP)

Cavalletti, Sofia. 2013. History of the Kingdom of God: Liturgy and the Building of the Kingdom. Part 2. (Chicago: LTP. Second Edition)

Cavalletti, Sofia. 1992. The Religious Potential of the Child. (Chicago: LTP. Revised Edition. 
Cavalletti, Sofia. 2002. The Religious Potential of the Child 6 to 12 Years Old. (Chicago: LTP. Revised Edition)

Cavalletti, Sofia, and Coulter, Patricia. 2010. Ways to Nurture the Relationship with God. (Chicago: LTP)

Gobbi, Gianna. 1998. Listening to God with Children. The Montessori Method Applied to the Catechesis of Children. (Loveland $\mathrm{OH}$ : Treehaus Communications)

Hattie, John. (2009) Visible Learning.A Synthesis of over 800 Meta-Analyses Relating to Achievement. (New York: Routledge)

Hyde, Brendan. 2011. "Montessori and Jerome W. Berryman: work, play, religious education and the art of using the Christian language system." British Journal of Religious Education, $33: 3,341-353$.

John Paul II Angelus Address: Sunday $6^{\text {th }}$ August, 1995, 1.

John Paul II. 2001. Ecclesia in Oceania

Lillard, Angeline Stoll. 2005. Montessori. The Science Behind The Genius. (New York: Oxford University Press)

National Association of the Catechesis of the Good Shepherd, USA. 2011. Training Manual, Level 1: 3 to 6 Years Old. (Chicago: CGSUSA)

National Association of the Catechesis of the Good Shepherd, USA. 2012. Training Manual, Level 2:6 to 9 Years Old. (Chicago: CGSUSA)

National Association of the Catechesis of the Good Shepherd, USA. 2013. Training Manual, Level 3:9 to 12 Years Old. (Chicago: CGSUSA, Draft, 2013)

Paul VI. 1970. "Address to the International Congress of Montessori Educators on the Centenary of the Birth of Maria Montessori." (1970)

Pope Francis, Evangelii Gaudium, 2013. B.

Pope Francis, Lumen Fidei, 2013. A.

Stewart, Sonja M. and Berryman, Jerome W. 1989. Young Children and Worship. (Louisville, KY. Westminster, John Knox Press)

Thomas Aquinas, Summa Theologica. 1981. (Westminster, Maryland: Christian Classics)

Webb, Stuart. 2007. "The Effects of Repetition on Vocabulary Knowledge." Applied Linguistics, Vol. 28 Issue 1, pp 46-65. 